\title{
LANGUAGE IDENTITY OF THE NATION AS A FACTOR OF THE MODERN SOCIETY CULTURE FORMATION
}

\author{
МОВНА ІДЕНТИЧНІСТЬ НАЦІЇ ЯК ЧИННИК ФОРМУВАННЯ КУЛЬТУРИ \\ СУЧАСНОГО СУСПІЛЬСТВА
}

Comprehensive extension of intercultural contacts and the globalization of the globe make necessary the studying of such cultural elements that are reflected in the language of any people in the nationally-cultural aspect. The problem of correlation and interrelation of language and culture has always generated considerable interest of many scientists and linguists, who, despite the diversity of approaches to the study of this question, consider the culture and language in interaction. Purpose of the research is to study the linguistic identity of the nation as a means of expression of the culture of any modern society and a significant factor in the ideological formation of the Ukrainian nation, influencing it of modern global globalization processes. The research methodology consists of general scientific methods such as analysis and synthesis, induction and deduction, analogy, method of ascent from abstract to concrete. In the process of considering the phenomena of socio-historical reality, the following methods were used: the unity of logical and historical, historical-comparative and structural-unctional analysis, existential, as well as socio-cultural and semiotic approaches. The scientific novelty of the study is due to the delineation of the global and local processes interaction in the linguistic identity context. The local and the global interaction in the modern socio-cultural space is a multifaceted and complex process that is an integral factor in the development of any society. The study of the national language identity of Ukraine in a globalized world is relevant and fundamentally important for understanding and forecasting the further development and modernization of Ukrainian society, developing criteria and scientific tools for analyzing different ongoing language processes, which are an extremely complex area of public life. In the article, the processes of globalization - intercultural dialogue, the unification of national languages, fragmentation, glocalization are singled out. Simultaneously with the process of unification, the beginning of the emergence of global forms of coexistence and their spread is the strengthening of the local response to the global, which can be quite unstable, contrary to the traditional context.

Key words: language, identity, nation, cultural creation, worldview, language competence, language identity.

Всебічне розширення міжкультурних контактів та глобалізація земної кулі роблять необхідним вивчення таких культурних елементів, які відображаються в мові будь-якого народу в національнокультурному аспекті. Однією з головних проблем досліджуваного суспільства $\epsilon$ взаємозв'язок мови та національної ідентичності. Проблема співвідношення та взаємозв'язку мови та культури завжди викликала значний інтерес у багатьох науковців та мовознавців, які, незважаючи на різноманітність підходів до вивчення цього питання, розглядають культуру та мову у взаємодії. Метою дослідження $\epsilon$ вивчення мовної ідентичності начії як засобу вираження культури будь-якого сучасного суспільства та суттєвого чинника світоглядного становлення української нації, впливу на неї сучасних світових глобалізаційних процесів. Методи дослідження. Насамперед використовуються загальнонаукові методи: аналіз та синтез, індукція та дедукція, аналогія, метод сходження від абстрактного до конкретного. Наукова новизна дослідження зумовлена окресленням взаємодії глобальних і локальних процесів у контексті мовної ідентичності. Взаємодія локального і глобального в сучасному соціокультурному просторі $\epsilon$ багатогранним та складним процесом, що є невід'ємним чинником розвитку будьякого суспільства. Вивчення національної мовної ідентичності України у глобалізованому світі $\epsilon$ актуальним та принципово важливим для розуміння та прогнозування подальшого розвитку та модернізаціі українського суспільства, розробки критеріїв та наукових інструментів для аналізу різних поточних мовних процесів, які $є$ надзвичайно складною сорерою суспільного життя. Висвітлено ідею ідентичності української мови, на основі якої суттєвим ядром є культура, яка визначає місце всіх видимих функкцій та інститутів мови. У статті виокремлено процеси глобалізації: міжкультурний діалог, унірікація національних мов, фррагментація, глобалізація. Виявляється амбівалентність глобального та локального - відкритість чи заперечення глобальних процесів - локальні форми модиорікуються, зливаючись у глобальну систему i, навпаки, формується новий зміст глобальних аспектів в умовах, характерних для певних місцевостей.

Ключові слова: мова, ідентичність, нація, культуротворення, світобачення, мовна компетентність, мовна ідентичність.
Introduction. The world civilization transformation into a single structural and functional system sets a new pace and new quality for the development of human coexistence various aspects and requires an intellectual understanding of this process. The planet geopolitical configuration acquires a qualitatively new 
look, rapidly changing priorities in their interests, ways and conditions of their achievement. Transnational entrepreneurship, the universalization of the scientific and information space, the all-encompassing dominance of the Internet, and the development of modern communications have made the world more accessible, but far from simpler in forms and ways of expression.

Today, no country in the world can stand aside from these processes. Either it will be able to adapt the rhythm, content, focus of its development to the rapid pace of general civilizational progress, in which the main driver of change is no longer material resources, not "living" human labor, but the total intellectual potential, information wealth, or will have to accept the fate of an outsider.

Comprehensive extension of intercultural contacts and the globalization of the globe make necessary the studying of such cultural elements that are reflected in the language of any people in the nationally-cultural aspect. One of the main problems of the society studying is the relationship between language and national (ethnic) identity. The problem of correlation and interrelation of language and culture has always generated considerable interest of many scientists and linguists, who, despite the diversity of approaches to the study of this question, consider the culture and language in interaction. The fact that the language has long been regarded as one of the main factors of ethnic identity, since language is one of the main members of the ethnic group. At the same time, we note that "national identity is a complex phenomenon, a meaningful filling of which for each country is specific" [14, p. 34].

Unprecedented in the history of mankind growth of the population's social mobility, technical and technological innovations and the flow of information, to which man is not adapted primarily psychologically, make the problem of self-identity universal. Identity is an important prerequisite for a safe and comfortable human life, social community, society as a whole. It becomes a kind of prism through which the events and features of society and the individual's modern life are considered, evaluated, studied. And only fates of identities (national, ethnic, personal) are that real magic crystal through which the contours of the future world are already visible today [3, p. 10].

Recent research and publications analysis. Since the $19^{\text {th }}$ century, the question about the interaction and interrelation of language and culture is one of the most discussed and studied in linguistics and, however, it has still not lost its relevance. For the first time in the history of linguistics, the attempt to solve this problem began V. von Humboldt, whose concept is based on the following principles [8]:

- material and spiritual culture are embodied in the language;
- every culture is national; its national character is expressed in language with the help of a special vision of the world;

- language has a specific internal form for each people;

- the internal form of speech is the expression of the "people's spirit", of its culture;

- language is a connecting link between man and the surrounding world.

According to $\mathrm{V}$. von Humboldt, language and culture are the forms of consciousness that reflect the worldview of a person and is a national form of embodiment of the material and spiritual culture of the people. Subsequently, the concept of V. von Humboldt continued to develop J. Galbraith, J. Charlier, S. Groche, O. Potebnya, G. Terborn and other researchers. However, all definitions of language converge in the main: language is a mean of communication, a mean of expressing thoughts.

The purpose is to study national language identity as a substantial factor in the worldview formation of the Ukrainian nation and the influence of modern world globalization processes on it.

Achieving this goal involves solving the following tasks:

- to clarify the basic theoretical and methodological approaches in understanding the concept of identity and to characterize modern approaches to the interpretation of the identity concept;

- to carry out the historical and philosophical analysis of the Ukrainian mentality properties;

- to reveal the interaction of global and local processes in the context of language identity.

- to analyze the phenomenon of national language identity;

- to outline the specifics of the language identity crisis in the context of globalization.

The object of study is national language identity in the context of globalization.

The research methods consist of general scientific methods such as analysis and synthesis, induction and deduction, analogy, method of ascent from abstract to concrete. In the process of considering the phenomena of socio-historical reality, the following methods were used: the unity of logical and historical, historical-comparative and structural-functional analysis, existential, as well as socio-cultural and semiotic approaches.

Main research material. The significance of the identity and identification problem is enhanced by a total rethinking of values, exoticism and pragmatism of people's worldviews, as well as a direct sense of vacuum in place of traditional lifestyles. Under such conditions, the awareness of super personal meanings and values of existence becomes urgent. It is no coincidence that in scientific and philosophical discourse at the turn of the century, researchers have attracted special attention from such categories as being, existence, mentality, identity. 
The rapid changes in the world associated with the growing and highly controversial processes of globalization are sharply actualizing and exacerbating, first of all, the problem of national identity, as it is eroding its traditional foundations. Never before in world history has this problem been so fatal as it is today. And never before has it affected virtually all nations and peoples of the world. The crisis of national identity has acquired such forms and scales that overcoming it means for many of them not only the choice of an adequate competitive development strategy. It has become a problem of national survival.

Ukraine is facing the need for such a choice, understanding of global transformations and its place in them. Modernity poses a number of questions to our state, in the answers to which we must find a new model of socio-cultural stability. This will make it possible to find guidelines for overcoming the crisis that has covered the main spheres of life, namely: spiritual and material, socio-cultural and socio-political. The processes taking place in these spheres are important for our society: national consciousness formation, the Ukrainian people worldview formation on the basis of their own cultural and language identity. The nations that occupy a prominent place in the world socio-cultural hierarchy have taken centuries to complete these processes, but our state needs to do so in a relatively short time, which is required by the rapidity of globalization movements.

In the current conditions of globalization processes intensification, the problem of preserving the national language identity of Ukrainians becomes especially relevant. After all, the general progress of the Ukrainian nation and the development of the Ukrainian state depend on a qualitative solution to this issue. On August 3, 2006, the Universal of National Unity proposed to unite the efforts of the public to implement many priorities of national progress, in particular, comprehensive development and functioning of the Ukrainian language as a basis for self-identification of the people and the state, development of culture and spirituality of the Ukrainian people. cultural space, etc. This confirmed the urgency of resolving these issues.

Modern linguistics seeks to understand the cultural consciousness of individual nations through linguistic means. "National consciousness in its basis is multidimensional. However, it does not doubt the fact that one of its identities is the language, and the national consciousness is expressed in the national language picture of the world". [10] Most linguists hold the view that any language, being a social phenomenon, can and should be considered not only from a purely linguistic point of view, but also, most importantly, with extra linguistic or cultural, because it is, on the one hand, is an integral part of the culture, and on the other is "the mirror" that reflects its originality, authenticity and richness. The culture of any country in the world is the main component of human existence as a social being. Human is in constant interaction with the outside world and society, collecting and analyzing information about them, thus, in the human mind reflects all possible realities and approaches to reality. The acquired knowledge is always expressed in language. Language does not exist outside the person, and the person does not exist outside the language. Language is an instrument of knowledge, with the help of which a person recognizes the world and culture in general. This is an instrument of culture: it forms a person, determines its behaviour, way of life, world outlook, mentality, national character, ideology [9; 12]. Language as a means of communication between people and culture, coordinates their joint activity as a significant means in the process of linguistic interaction, during which the coordination of communicative activities is carried out on the basis of language system resources. Language is involved not only in the transfer of thought about something already known, but also in formation of a new thought about a new, still unknown phenomenon, process, object.

Language is both a condition for the development of culture and society, and a product of human culture and the society genesis. Given this, language has two main functions in human society:

1) communicative;

2) the function of reflecting reality and the formation of thinking and consciousness categories.

Language also performs other functions: representative, expressive, appellate, nominative, cognitive, emotional, magical, and others. Thus, language is the basis of speech, serves for human communication, is a means of expression and communication of thoughts, a tool for forming categories of thinking and consciousness, language is also able to express the whole set of knowledge and ideas about the world.

The language of every nation is not only the product of many generations, it, according to $M$. Heidegger, is decisive for the essence of man. "A person would not be a person if he was denied to speak continuously, everywhere, about everything, in various variations and mostly not harnessed to "it is". If language allows, the human essence is in language" [7, p. 203]. The philosopher believes that for a person the world of native language is "the house of being", "the most intimate bosom of culture". This is the natural psychological environment of human existence, the figurative and mental "air" through which he breathes, in which consciousness lives" [7, p. 203].

Domestic linguist $\mathrm{O}$. Potebnia developed the idea according to which language participates not only in the people's worldview formation, but also in the very development of thought: "A person who speaks two languages, moving from one to another, changes at the same time the nature and direction of his opinion, and so that its efforts only change the path of thought, 
and its further course is affected only indirectly. This effort can be compared with what makes a switchman who transfers the train to other rails" [12, p. 377]. According to O. Potebnia, the word is not just a linguistic means, but a fundamental, basic principle of the nation's consciousness; in it, language, is already embedded all the diversity of the national vision of the world (visual, abstract and mythological). Each of the world's languages, as the linguist emphasized, is a profoundly different system of methods of thinking, which determines its uniqueness.

Language can be a bright marker of identity for some people or ethnic group as a whole and not be so for others. The association between language and identity depends on the social context in which a particular ethnic group is located. For some groups, language may be a more important component of identification than for others. In a number of ethnic communities, the loss of any ethnic feature, including the loss of language, does not lead to assimilation, but causes a kind of "disturbance of ethnic identity, which seeks other symbols of ethnic heritage" [2, p. 20].

It is known that some ethnic communities have been able to continue their existence as separate ethnic groups without assimilating after switching to another language as a means of communication. According to this view, preference is always given to the usefulness of language, rather than its symbolic or emotional value. Proponents of this view agree that language can be an important component of ethnic identity, but that identity can experience - and continues to experience - the loss of the group's primary language. Thus, it is necessary to distinguish between such concepts as "use of language", "language competence" and "language identity" [9, p. 144].

In particular, K. Eastman argues that the use of language is only a superficial feature of ethnic identity. Acceptance of another language affects only the linguistic aspect of our identity, not the identity itself: "... there is no need to worry about preserving ethnic identity, because the only dimension is the language we use" [5, p. 256].

We can observe such a situation, for example, in Great Britain. Great Britain is a multinational state, its indigenous inhabitants are Scots, Welsh, Irish have their own national-territorial entities, whose official languages are the indigenous language and English. However, English has almost completely supplanted indigenous languages. These languages are still not forgotten, but few people speak them. The situation is similar in neighboring Ireland, where for two centuries English has virtually supplanted Irish as the national language, although the latter still retains the status of an official language. As in other national formations, here the "native" language is spoken by a few residents.

In the scientific literature, the opinion is expressed that the diversity of national languages should be replaced by a single universal language and the com- mon language of future humanity will be English. Languages in general, the national language in particular, are a means of civilization, the unification of peoples and regions into a single, namely the unity of civilization, the historical significance of which is quite obvious. For reasons that are, of course, objectively historical, in different historical epochs certain languages have played the role of the language of international communication. This was the case with Greek and Latin in antiquity and the Middle Ages. Today, English plays a similar role.

Whether we like it or not, today English is beginning to play the role that Latin played in medieval Europe. It becomes the "new Latin", the "alphabet of education". Computers "speak" English, which gives it priority over other languages. About 80 percent of information on electronic media today is written in English. 1.5 billion people communicate with it every day. Many English texts are now created by those for whom English is not a native language. International English appears as "McLanguage" - simplified, reduced, without hidden connotations and grammatical subtleties. In this form, O. Karmin reasonably emphasizes, it is unlikely to become a full-fledged language of world culture, able to replace national languages [9, p. 57].

Bilingualism can be a positive phenomenon only at the level of individual communication. At the level of public communication, bilingualism has an internal contradiction, which makes it impossible to apply it in practice in language policy. The use of two languages in the communication of a society is always superfluous, each society naturally tends to be monolingual. Interpersonal communication in different languages, even in cases of bilingual communication, creates a number of difficulties or even misunderstanding.

State measures on language policy should be based primarily on the realities of the language situation, taking into account regional and external factors, and contain consolidating aspects of the language sphere, which would indicate common self-identification, without rejecting other forms of communication and other languages. With low legitimacy, the policy of introducing the Ukrainian language will not bring the expected results. Methods of structural violence aimed at creating a homogeneous Ukrainian-speaking environment will negatively affect social stability, as violent identity change is a very painful process.

European experience shows that certain approaches should dominate in language policy. The main condition is the recognition of the Ukrainian language as the only state language, which means ensuring the activity and document circulation of state authorities in the Ukrainian language throughout the country. To do this, it is necessary to introduce a set of measures that would guarantee knowledge of the Ukrainian language by civil servants. The Ukrainian language should become prestigious and 
necessary for a career. "The language in its literary form has become a high level of development. It has a perfectly elaborated grammar, a formed scientific and technical terminology, a developed stylistic system capable of ensuring communication and understanding in all spheres of social life. Its cognitive, expressive and communicative potential is extremely powerful." [1, p. 6]

European experience shows that certain approaches should dominate in language policy. The main condition is the recognition of the Ukrainian language as the only state language, which means ensuring the activity and document circulation of state authorities in the Ukrainian language throughout the country. To do this, it is necessary to introduce a set of measures that would guarantee knowledge of the Ukrainian language by civil servants. The Ukrainian language should become prestigious and necessary for a career.

The second main provision should be the development and implementation of the concept of Ukrainian cultural product. It is he who must be supported by the state.

Among other things, the language policy of Ukraine should be based on the following practical considerations:

- the Ukrainian language should be supported as a basis for creating a national market for information products (printed, television and film, music, theater, education, etc.);

- the approval of the Ukrainian language should not take place at the expense of legislative restrictions on Russian and other languages.

Conclusions. The study of national language identity of Ukraine in a globalized world is relevant and fundamentally important for understanding and forecasting the further development and modernization of Ukrainian society, developing criteria and scientific tools for analyzing different ongoing language processes, which are extremely complex area of public life. In the search for one's own national language identity, ideas are needed that are adequate to the realities of the processes taking place in a globalized world, taking into account the uniqueness of the Ukrainian community and language itself. There can be no "eternal" answers to these "eternal" questions of identity. The discussion continues. And the future of Ukraine will depend to some extent on how fruitful its results will be.

In the article, the processes of globalization such as intercultural dialogue, the unification of national languages, fragmentation, glocalization have been singled out. Globalization can significantly change the worldview of the individual and society as a whole. The problems of interaction of global (world) and local (national, regional) processes in the context of language identity have been investigated.
Simultaneously with the process of unification, the beginning of the emergence of global forms of coexistence and their spread is the strengthening of the local response to the global, which can be quite unstable, contrary to the traditional context. The ambivalence of the global and the local has been revealed. The openness or denial of global processes - local forms have been modified, merging into the global system and, conversely, new content of global aspects is formed in conditions specific to certain localities.

The Ukrainian language identity has been highlighted, based on which the core is the substantial core of culture, which determines the place of all visible functions and institutions of language. This core is the universals of the Ukrainian language, the archetypes of the Ukrainian mentality and culture.

\section{REFERENCES:}

1. Azarova L. Language as a determining factor of identity of the Ukrainian nation. Scientific Bulletin of the National University of Bioresources and Nature Management of Ukraine. Series : Philological sciences, Vol.292, 2018. p. 24-32

2. Аклаев А.Р. Язык в системе национальных ценностей и интересов. Духовная культура и этническая идентичность. Мышление и речь. Москва, 1999. 256 с.

3. Bennet M.J. Towards Ethnorelativism: A Developmental Model of Intercultural Sensitivity. Education for the Intercultural Experience. 2009. 271 p.

4. Charlier J., Groche S. Now European Integration is Eroding National Control over Educating Planning and Policy. 2006. 368 p.

5. Eastman C. Language, ethnic identity and change. Linguistic Minorities, Policies and Pluralism.1994. 332 p.

6. Galbraith, J. K. The New Industrial State. 2012. $515 \mathrm{p}$.

7. Хайдеггер М. Время и бытие: статьи и выступления. Москва : Высш. шк., 2000. с. 254-259.

8. Гумбольд В. О различии в строении человеческих языков и его влиянии на духовное развитие человечества (1830-1835) Избранные труды по языкознанию. 2010.

9. Кармин А. Философрия культуры в инфрормационном обществе: проблемы и перспективы. Проблемы фрилософрии. 2006. 118 р

10. Ковальова Т. Теорія нації як методологічна основа формування державної мовної політики, Ефективність державного управління, Випуск 1 (62), T. 1. URL: http://edu.Ivivacademy.com/ article/view/205766 2020

11. Liebkind K. Social Psychology. Handbook of Language and Ethnic Identity. 2009. pp.140-151

12. Міхновський М. Справа української інтелігенції у програмі Української народної партії (Фрагменти). 2007. С. 54-81

13. Потебня А. Эстетика и поэтика. Москва, 1985 $302 \mathrm{p}$.

14. Rudenko Yu. National identity as a component of civilization identity of the national security context, Vol.18, 2016. p. 34. 